HETEROCYCLES, Vol. 80, No. 1, 2010, pp. 13 - 14. ๑ The Japan Institute of Heterocyclic Chemistry DOI: $10.3987 / C O M-09-S(S) C V$

\title{
Curriculum Vitae of Akira Suzuki
}

Name: Akira Suzuki Professor Emeritus, Hokkaido University, Sapporo, Japan

Address: 3-2-905, Aino-sato 2-Jo, 6-Chome, Kita-ku, Sapporo, 002-8072 Japan

Tel: $\quad+81-11-778-7866$ or $+81-11-386-5670$

E-mail: asuzuki@eng.hokudai.ac.jp

Date of Birth : 12 September 1930

Education: BS in Chemistry, 1954 (Hokkaido Univ.). Ph D in Chemistry, 1959 (Hokkaido Univ.). Postdoctoral, 1963-65 (Purdue Univ., U.S.A., Professor Herbert C. Brown).

Career to Date: Research Assistant, 1959 (Hokkaido Univ.). Associate Professor, 1961 (Hokkaido Univ.). Professor, 1973-94 (Hokkaido Univ.). Professor, 1994-95 (Okayama Univ. of Science). Professor, 1995-2002 (Kurashiki Univ. of Science and Arts). Invited Professors; 1988 (Univ. of Wales, UK), 2001 (Purdue Univ., USA), 2002-2003 (National Taiwan Univ. and Academia Sinica, Taiwan).

Publications: 341 Research Articles in Chemistry to International and Internal Journals (until April 2008).

Memberships: Chemical Society of Japan (Vice-president, Director, and Editorial Member of the Bulletin of the Chemical Society of Japan). Society of Synthetic Organic Chemistry, Japan (Director and President of Tohoku-Hokkaido Branch). American Chemical Society.

Awards and Honors: Weissberger-Williams Lectureship Award, 1986 (Eastman Kodak Co., USA). Testimonial, 1987 (Korean Chemical Society). Chemical Society of Japan Award, 1989 (Chemical Society of Japan). Professor Emeritus, 1994 (Hokkaido Univ.). DowElanco Lectureship Award, 1995 (Ohio State Univ., USA). Herbert C. Brown Lecturer Award, 2000 (Purdue Univ., USA). Weissberger-Williams Lectureship Award. 2001 (Eastman Kodak Co., USA). Distinguished Lecturer Award, 2001 (Queen's University, Canada and Pfizer Co., USA). Honorary Member, Argentine Organic Chemistry Society, 2001 (Argentina). Synthetic Organic Chemistry Japan Special Award, 2004 (Society of Synthetic Organic Chemistry, Japan). Japan Academy Award, 2004 (Japan Academy). Honorary Member of Chemical Society of Japan, 2005. Honorary Member of Synthetic Organic 
Chemistry, Japan, 2005. The Order of the Sacred Treasure, Gold Rays with Neck Ribbon, 2005 (Japanese Government). Distinguished Emeritus Professor, 2006 (Hokkaido University). Honorary Professor, 2006 (Shanghai Institute of Organic Chemistry, Chinese Academy of Sciences, China). P. Karrer Gold Medal, 2009 (Zürich University, Switzerland).

Research Field: Synthetic Organic Chemistry 